\title{
SIGNET RING CELL GASTRIC CARCINOMA- A CASE REPORT
}

Rajesh Daniel1, Maramreddy Lokesh Reddy², Prakash Sadasivam³, Parivallal Damodaran 4 , Abhinav Bharadwaj Rajkumar 5

${ }_{1}^{1}$ Assistant Professor, Department of General Surgery, SRM Medical College Hospital and Research Centre, Kattankulathur, Kancheepuram, Tamilnadu, India.

2Postgraduate Student, Department of General Surgery, SRM Medical College Hospital and Research Centre, Kattankulathur, Kancheepuram, Tamilnadu, India.

${ }^{3}$ Assistant Professor, Department of General Surgery, SRM Medical College Hospital and Research Centre, Kattankulathur, Kancheepuram, Tamilnadu, India.

${ }^{4}$ Postgraduate Student, Department of General Surgery, SRM Medical College Hospital and Research Centre, Kattankulathur, Kancheepuram, Tamilnadu, India.

${ }^{5}$ Postgraduate Student, Department of General Surgery, SRM Medical College Hospital and Research Centre, Kattankulathur, Kancheepuram, Tamilnadu, India.

HOW TO CITE THIS ARTICLE: Daniel R, Reddy ML, Sadasivam P, et al. Signet ring cell gastric carcinoma- a case report. J. Evolution Med. Dent. Sci. 2018;7(40):4399-4400, DOI: 10.14260/jemds/2018/981

\section{PRESENTATION OF THE CASE}

This 39-year-old female patient came to surgical outpatient department with the complaints of non-radiating upper abdominal pain and non-bilious vomiting for 1 week duration. There was history of loss of appetite, loss of weight and melena for past 1 month. ${ }^{1-3}$ On examination, the patient was found to be poorly nourished, dehydrated and pale. There was no icterus/ no pedal oedema and no significant supraclavicular lymphadenopathy.

Blood investigations showed $\mathrm{Hb}$ as $10.3 \mathrm{~g} / \mathrm{dL}, \mathrm{PCV}-34 \%$, WBC- 6,400 cells/cmm, Platelets- 2,13,000 cells/cmm and ESR- $02 \mathrm{~mm}$. The blood grouping was A positive. Serum electrolytes assessment showed sodium levels of $135 \mathrm{mEq} / \mathrm{L}$, Potassium- 3.9 millimoles/lit, Chloride- $103 \mathrm{mEq} / \mathrm{L}$ and Bicarbonate levels of $26 \mathrm{mEq} / \mathrm{L}$. Renal function tests revealed Urea level as $27 \mathrm{mg} / \mathrm{dL}$ and Serum creatinine level as 0.9 $\mathrm{mg} / \mathrm{dL} .4,5,6$

Upper gastrointestinal scopy done in this patient showed an Ulcerative growth involving the whole circumference of the antrum from the incisura to $1 \mathrm{~cm}$ start-up pylorus and lumen appeared narrowed (Figure 1).

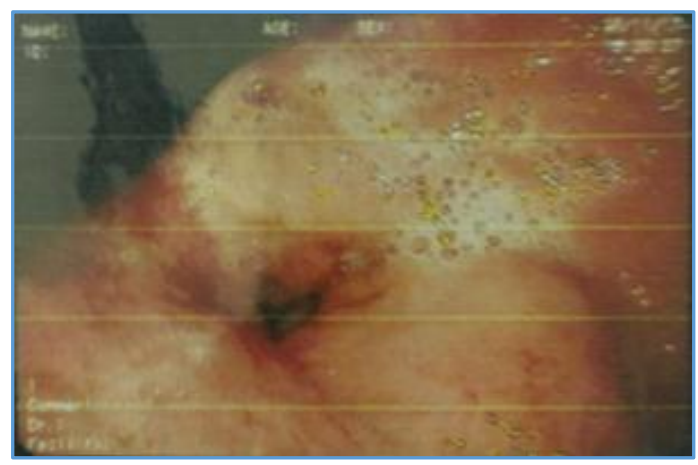

Figure 1. Upper Gastrointestinal Scopy showing Proliferative Growth in the Antrum

'Financial or Other Competing Interest': None.

Submission 20-04-2018, Peer Review 15-09-2018,

Acceptance 21-09-2018, Published 01-10-2018.

Corresponding Author:

Maramreddy Lokesh Reddy,

Postgraduate Student,

Department of General Surgery,

SRM Medical College Hospital and Research Centre,

Kattankulathur, Kancheepuram, Tamilnadu, India.

E-mail: loksays007@gmail.com

DOI: $10.14260 /$ jemds $/ 2018 / 981$
Multiple biopsies taken from the proliferative growth and sent for histopathological examination. Biopsy findings revealed poorly differentiated Adenocarcinoma involving antrum. Medical oncologist's opinion was obtained.

USG Abdomen showed gastric antral wall thickening of length $1.7 \mathrm{~cm}$. Liver was normal and there was no free fluid. No evidence for distant spread. CECT abdomen and chest revealed circumferential wall thickening noted in antropyloric region extending for a length of $6.6 \mathrm{~cm}$ with a wall thickness of $2 \mathrm{~cm}$ causing lumen narrowing. There was no retroperitoneal involvement and no perigastric nodes. ${ }^{7,8}$ Preoperative workup was done. Patient was taken up for D2 subtotal gastrectomy.

Figure 2 shows intraoperative findings. There was gastric antral wall thickening and proliferative growth in the antrum.

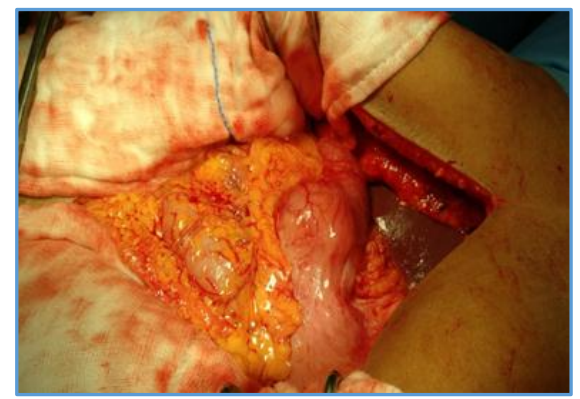

Figure 2. Intraoperative Findings showing Proliferative Growth and Antral Thickening

Figure 3 shows the excised growth sent for histopathological examination. Histopathology showed focus of intramucosal signet ring cell carcinoma invading the lamina propria (T1a) (A) and Signet ring cell carcinoma invading muscularis propria. Tumour cells had predominant cytoplasmic mucin and eccentrically placed crescent-shaped nucleus.

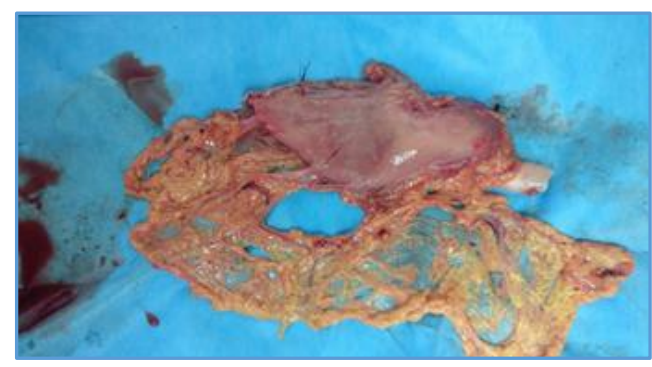

Figure 3 
Post-operative status of the patient was found to be uneventful.

\section{DIFFERENTIAL DIAGNOSES}

1. Acute Gastritis.

2. Chronic Gastritis.

3. Atrophic Gastritis.

4. Gastric Lymphoma.

5. GIST.

6. Peptic Ulcer Disease.

7. Gastric Outlet Obstruction.

\section{CLINICAL DIAGNOSIS}

Abdomen examination revealed that there was no tenderness, no mass, no free fluid and no visible gastric peristalsis. With this history the provisional diagnosis was made, as this is a case of gastric malignancy with gastric outlet obstruction.

\section{PATHOLOGICAL DISCUSSION}

In this study, we are reporting about a 39 years old female patient presenting with the complaints of non-radiating upper abdominal pain and non-bilious vomiting. There was loss of appetite and weight. Clinical examination revealed that the patient was pale. There was no tenderness, no mass, no free fluid in the abdomen and no visible gastric peristalsis. Upper GI scopy showed ulcerative growth in the antral region. ${ }^{9,10}$ Subtotal gastrectomy was done in this patient. Histopathological examination reported Signet ring gastric carcinoma.

Similar case has been reported from Nigeria ${ }^{11}$ where an 84-year-old local lady presented with upper, central abdominal ache of months duration with history of vomiting, loss of weight and loss of appetite. Scopy findings revealed that the prepyloric and pyloric portions of the stomach were completely taken over by a huge amorphous, fungating mass which had multiple ulcerating areas and had led to the near complete destruction of the normal architecture. The corpus and fundal regions were free of abnormality. The histopathology report showed the antral lesion came back as Signet ring cell carcinoma. ${ }^{11}$

As per WHO's classification, Signet ring cell carcinoma is defined as a poorly cohesive carcinoma composed predominantly of tumour cells with prominent cytoplasmic mucin and a crescent shaped nucleus eccentrically placed.12 SRCC is the most aggressive in nature. A California-based study found that SRCA were more likely to be found in women and in the distal stomach. ${ }^{13}$

SRCC has a specific oncogenesis that differ from that of tubular gastric adenocarcinoma. Two main pathologic processes at a cellular level are loss of cell-cell adhesion molecules and accumulation of mucin in large vacuoles. Ecadherin which is encoded by CDH1 gene is a cell-cell adhesion molecule and seems to play a key role in carcinogenesis. Other adherence molecules also involve such as somatic mutations of $\beta$-catenin/ APC genes or dysregulation of the Wnt/ $\beta$-catenin pathway. In SRCC, accumulation of mucins like MUC1, MUC2, MUC4, MUC5AC, MUC6 results in large vacuoles, which could therefore play a role in carcinogenesis. MUC4 has been reported to increase activation of ErbB2/ErbB3 complexes. Finally, hormonal theory in which oestrogen is involved in tumour initiation or progression or both has been developed to explain the increased incidence in women of SRCC.

\section{DISCUSSION OF MANAGEMENT}

SRCC is highly resistant to chemotherapy and radiotherapy. Paradoxically, SRCC is more frequent in early gastric cancer than in advanced gastric cancer. High chances of recurrence have been reported with SRCC. Better survival rates have been reported for SRCC than for non-SRCC tumours. ${ }^{14}$

\section{FINAL DIAGNOSIS}

This is a case of Signet ring gastric carcinoma.

\section{REFERENCES}

[1] https://www.wcrforg/int/cancer-facts-figures/dataspecific-cancers/stomach-cancer-statistics

[2] Jemal A, Bray F, Center MM, et al. Global cancer statistics. CA Cancer J Clin 2011;61(2):69-90. [Erratum in: CA Cancer J Clin 2011;61:134]

[3] Schlansky B, Sonnenberg A. Epidemiology of noncardia gastric adenocarcinoma in the United States. Am J Gastroenterol 2011;106(11):1978-85.

[4] Anderson WF, Camargo MC, Fraumeni JF Jr, et al. Agespecific trends in incidence of noncardia gastric cancer in US adults. JAMA 2010;303(17):1723-8.

[5] Zhu AL, Sonnenberg A. Is gastric cancer again rising? ] Clin Gastroenterol 2012;46(9):804-6.

[6] Watanabe H, Jass JR, Sobin LH, et al. Histological typing of oesophageal and gastric tumours. WHO International Histological Classification of Tumours No. 18. $2^{\text {nd }}$ edn. Berlin, Germany: Springer 1990.

[7] Abdulkareem FB, Onyekwere CA, Awolola NA, et al. A clinicopathologic review of malignant gastric tumours in Lagos, Nigeria. Nig Q J Hosp Med 2010;20(2):49-54.

[8] Bamboat ZM, Tang LH, Vinuela E, et al. Stage-stratified prognosis of signet ring cell histology in patients undergoing curative resection for gastric adenocarcinoma. Ann Surg Oncol 2014;21(5):1678-85.

[9] Taghavi S, Jayarajan SN, Davey A, et al. Prognostic significance of signet ring gastric cancer. J Clin Oncol 2012;30(28):3493-8.

[10] Henson DE, Dittus C, Younes M, et al. Differential trends in the intestinal and diffuse types of gastric carcinoma in the United States-2000: increase in the signet ring cell type. Arch Pathol Lab Med 2004;128(7):765-70.

[11] Aderemi O, Nicholas A. A case of signet ring cell gastric cancer with spread to the esophagogastric junction coexisting with Barretts esophagus. OA Case Reports 2014;3(5):50.

[12] Lauwers G, Carneiro F, Graham D, et al. Classification of tumours of the digestive system. $4^{\text {th }}$ edn. Lyon: IARC Press 2010: p. 48-58.

[13] Theuer CP, Nastanski F, Brewster WR, et al. Signet ring cell histology is associated with unique clinical features but does not affect gastric cancer survival. Am Surg 1999;65(10):915-21.

[14] Ha TK, An JY, Youn HK, et al. Indication for endoscopic mucosal resection in early signet ring cell gastric cancer. Ann Surg Oncol 2008;15(2):508-13. 